\title{
The Regulation of Renewable Resources to Promote Energy Efficiency in Sustainable Buildings in South Africa: A Legal Analysis \\ Prof CM van der Bank
}

Human Sciences, Vaal University of Technology

riana@vut.ac.za

Marjoné van der Bank

Human Sciences, Vaal University of Technology

marjonevdb@vut.ac.za

Doi:10.5901/mjss.2014.v5n23p2224

\begin{abstract}
Claims associated with the environment increasingly influence the area of human and fundamental rights. It is widely acknowledged that a direct well-designed relationship exists between the search for achieving environmental protection generally, and the protection of environmental rights. Since local government operates closer to citizens (the principle of subsidiarity) than any other level of government, it is obvious that it may be expected of it to also play an important role in the management and regulation of matters that affect the environment. This study questions the extent to which legislation governing the use of renewable and natural resources assist in developing sustainable building as provided for in South African environmental and local government legislation. This study provides a theoretical literature review of energy efficiency, categories of and different perspectives on environmental rights in general. The notion of local environmental governance is also attended to in this literature review. This study highlights one way in which South Africa can become more energy efficient, namely by applying sustainable building in the local context. The South African National Standards (SANS) 10400-XA: 2011 finds its application specifically on environmental sustainability and energy usage in buildings.
\end{abstract}

Keywords: Environmental right, local government, energy efficiency, renewable and natural resources, sustainable development and green building.

\section{Introduction}

The following article will be based on how the regulation of renewable resources can promote energy efficiency in sustainable building. The problem will be addressed where after the different policies, documents and legislation will be discussed. After the discussion, a conclusion will be drawn. This discussion will consist of a literature review of relevant textbooks and articles. Primary and secondary source material will be subjected to critical analysis which will give rise to the conclusion.

\section{The Problem of Renewable Energy in Sustainable Building}

Buildings have a significant impact on energy use in the environment. Buildings, including office blocks, manufacturing facilities and homes account for more than 40 percent of the world's total energy consumption, according to the Green Building Council of South Africa (GBCSA) (Green Building Council of South Africa 2011 http://www.gbcsa.org.za and also Siemens $2010 \mathrm{http}: / / \mathrm{www}$.us.siemens.com/sustainable -cities/index.html). The energy used by the ebuilding sector continues to increase, primarily because new buildings are constructed faster than old ones retired. For this reason it is argued that if sustainable building were to be constructed and implemented, the environmental impact of the built environment would be reduced (Green Building Council of South Africa 2011 http://www.gbcsa.org.za and also Siemens 2010 http://www.us.siemens.com/sustainable -cities/index.html). GBCSA developed South Africa's first voluntary sustainable building rating tool: the Green Star, which aims to calculate the environmental attributes of new commercial office building as well as the major base building restoration of existing office facilities (Davenport 2008 http://www.engineeringnews.co.za/print-version/sas-first-green-building-rating-tool). Another minus is that highly volatile energy rates make for difficult tracking over time. 


\section{Renewable Energy vs Energy Efficiency}

Energy is the potential to do work of some kind, for example to move something, change something, to activate something or to stop something happening. Renewable energy deals with the supply side of energy, while energy efficiency deals with the demand side of energy (Murombo and Du Plessis Energy Efficiency: New Strategies for improving South African Energy Laws 3). Renewable energy is from an energy resource that is replaced by a natural process at a rate that is equal to or faster than a rate at which that resource is being consumed. Renewable energy is any energy source that is naturally replenished, like that derived from solar, wind, geothermal or hydroelectric action. Renewable energy is a subset of sustainable energy. South Africa has a high level of renewable energy potential. Energy efficiency is thus using less energy to provide the same service. Energy efficiency contests the assumption that we need more and more energy inputs to satisfy our social and economic aspirations, but energy efficiency is often treated dismissively. Energy efficiency is not as exciting as new sources of supply. Great engineering ventures of ultra-deep water oil exploration, giant pipelines snaking across the globe, colossal new coal mines, or returning to nuclear energy is more exciting. According to Barton the entrenched assumption is that there is a need for more fuel supply, and that South Africa's science, technology and engineering brilliance ought to be employed to go and get it. This assumption is most common in an environmentally orientated energy circles as to any other (Barton 2008).

Energy efficiency is not energy conservation. Energy conservation is reducing or going without a service to save energy. Turn off a light is energy conservation. Replacing an incandescent lamp with a compact fluorescent lamp is energy efficiency. Therefore it can be seen that South Africa have an energy problem and a soluble solution is needed to address this energy problem. A simple way of improving energy efficiency is to change behaviour. The efficiency of an appliance or technology is determined by the amount of energy needed to provide the energy service.

\section{South African Energy Laws}

The Constitution of the Republic of South Africa, 1996 (hereafter referred to as the Constitution) have fundamental human rights, amongst which are, to provide every person with the right to an environment that is not harmful to their health or well-being and a right to an environment that is protected for the benefit of present and future generations, (s 7(2) read in conjunction with ss 24(a) and (b) of the Constitution) and it is the state's duty to give effect to these rights. Section 7(2) of the Constitution places a positive and negative (a duty to desist) duty on the state to respect, protect, promote and fulfil the rights in the Bill of Rights (Brand D and Heyns C (eds) Socio-Economic Rights in South Africa (PULP Pretoria 2005) 257-258). Therefore the assumption that can be drawn is in fulfilling section $7(2)$ of the Constitution, the State must respect, protect, promote and fulfil the obligation that every person has the right to an environment that is not harmful to their health or well-being and an environment that is protected for present and future generation's benefit. In other words no person has the right to an absolutely clean and pollution-free environment.

Local governments in South Africa are bound by national legislation, in addition to various environmental and local government laws, to regulate building. South African municipalities are subject to Schedule 4(B), read with section 156(1), of the Constitution, which states that municipalities (local government) have the power to execute law-making and executive powers in relation to buildings. The duty to provide every person with an environment that is not harmful to his or her health or well-being for the benefit for present and future generations is prolonged in section 4 of the Local Government: Municipal Systems Act 32 of 2000 (hereafter the Systems Act).

The National Environmental Management Act 107 of 1998 (NEMA) in South Africa provides for an environmental legislative and policy framework for the implementation of sustainable development - obviously including building. The principles that are set out in NEMA apply throughout the Republic of South Africa to the actions of all organs of state. These principles serve as a general framework and must be considered in environmental management and implementation plans, by any organ of state (section 2(1)(a) and (b) of NEMA). The objectives of NEMA are to give effect to s 24 of the Constitution by providing an environment that is not harmful to the health and well-being of the inhabitants of South Africa and to developing a framework for the integration of good environmental management into all developmental activities (Preamble of NEMA). NEMA makes provision that relates to sustainable development and local government. This can be seen in the broad spectrum of basic environmental principles of NEMA (section 2 of NEMA). The principles in section 2 of NEMA places a direct duty on the state (which includes municipalities) to respect, protect, promote and fulfil the social and economic rights in the Bill of Rights (section 2(1)(a) of NEMA). 


\section{What is Energy Efficiency?}

When referring to energy efficiency, usually the discussion relates to building, industrial energy efficiency, the generation of energy, transportation and energy usage, consumption and technology. According to the National Energy Act 34 of 2008 energy efficiency is "the economical and efficient production and utilisation of energy carrier or resource"; whereas energy resources means the "non-value added material or mineral that can be used to produce energy or be converted to an energy carrier "and energy carrier is defined as "a substance or system that moves or carries energy in a usable form from one place to another". These definitions must be read in conjunction with a definition of renewable energy which means "energy generated from natural non-depleting resources including solar energy, wind energy, biomass energy, biological waste energy, hydro energy, geothermal energy and ocean and tidal energy". Taken into consideration the definition of "energy carrier" and "energy resource" both the definitions make reference to non-renewable and renewable forms of energy. In certain sectors the use of renewable energy is seen as one of the tools to become more energy efficient, however the renewable energy technology must itself be energy efficient during its own life cycle (Murombo and Du Plessis Energy Efficiency: New Strategies for improving South African Energy Laws).

\section{Regulation of Energy Efficiency}

In the new constitutional dispensation, the government of the Republic of South Africa has been divided into three spheres. According to the Constitution these spheres are distinctive, interdependent and interrelated (section 40 (1) of the Constitution). The regulation of energy efficiency is governed on a national level by the Department of Energy and Energy Efficiency Directorate. On a policy level it is regulated by different Policies, strategies, targets and legislation and on local level by Municipal policies and by-laws.

\section{Sustainable Building}

In order to clarify the origin, content and scope of sustainable building, the National Building Regulations and Building Standards Act 103 of 1977 (hereafter NRBS) specifically regulates building in South Africa. The objectives of the NRBS are to promote uniformity in the law that relates to the erection of buildings in areas where the local government have jurisdiction. A further objective of the NRBS is to prescribe building standards and to regulate any matter that relate to building standards (Preamble of the NRBS). The Department of Trade and Industry promulgated in GG R711 no 34586 of 9 September 2011 country-wide regulations for sustainable development of buildings in South Africa. Although the NRBS does not specifically make reference to sustainable building, the Minister of Trade and Industry has the power to incorporate matters on sustainable development in the regulations that is made to the act. An example that this has been done and is manifested in the regulation (GG R711 no 34586 of 9 September 2011) which make reference to energy usage in buildings.

The South African Bureau of Standards (hereafter SABS) National Committee approves or disapproves the South African standards on building regulations and the South African National Standards (SANS) is developed according to the objectives of SABS (National Committee SABS 2011 www.sabs.co.za).

\section{Tax Incentives}

Local governments may impose property rates and surcharges on fees for services that are provided by the municipality or on behalf of the municipality (section 229 of the Constitution). The taxation that a municipality charges is defined as taxation on property (section 229(1)(a) of the Constitution. Also see White Paper on Local Government, 1998 at 135). The property tax requires the owner of the immovable property within the jurisdiction of the municipality to pay tax (that is based on the valuation of the property) to the specific municipality (Bekink Local Government Law 432). Bekink argues that local governments should have latitude with regard to property taxes within their jurisdictions due to the fact that a municipality can reflect its own unique circumstances and local economic objectives (Bekink Local Government Law 344). The Income Tax Act in section 12i allows that a tax reduction to be given to companies that engage in the improvement of energy efficiency. This energy efficiency improvement must conform to the "reported savings" approach that is outlined in the National Standard 50010 for the "measurement and verification of energy efficiency savings" as it is issued by the South African Bureau of Standards.

Brownfield (abandoned vacant, derelict or underutilized commercial and industrial properties where precedent actions have resulted in definite or supposed contamination) (Ottawa http://ottawa.ca/sites/ottawa.ca/files/migrated/ 
files/con025271.pdf 3) and Greenfield (sites that have not been built on prior to and are often rural or countryside areas) (Bamford, M Brownfield vs Greenfield sites: What are the issues involved? 1) efficiency improvements must adhere to certain criteria and must receive requisite verification by SANEDI. For the purposes of this study, the author will propose that should a person promote the principle of sustainable building on an immovable property, the municipality should encourage sustainable building through the decreasing of the property tax, or an alternative incentive, on the specific immovable property, like the incentive that companies (discussed above) can receive.

\section{Principle of Subsidiarity}

Lower levels of government usually favour the devolutionists principle of subsidiarity, the concept means that governance should take place as close as possible to the citizen (De Visser Local government Bulletin 16-17). Subsidiarity is widely invoked and supported, but in practice it is also highly contested and could be used to justify a variety of practical outcomes in different circumstances. This translates in the protection of lower spheres of government (local government) against the undue interference by the national government. Therefore, when implementing the principle of subsidiarity, it is argued that the lower level of government (local government) are closer to the citizens and can therefore establish and distinguish the needs of the citizens and address them as they come (De Visser Local Government Bulletin 16-17). The subsidiarity principle ensure the human right in the local government and add to the development of local initiatives and the civil society. Local governments are protected by the Constitution in s 156(4) and national and provincial governments are encouraged to transfer the functions to local governments where it is possible. This principle could provide a useful benchmark for assessing, and for reforming, program design and funding arrangements.

\section{National Building Regulation}

SANS $10400-X$ finds its application in environmental sustainability in the national building regulations. The SANS 10400XA: 2011 standard has been developed to promote energy efficiency in buildings (GG R711 no 34586 of 9 September 2011). The National Regulator for Compulsory Specifications (NRCS) is responsible for the administration of the technical regulations and to make sure that the building industry is on track concerning energy efficiency (Lemmer 2011 http://www.kznia.org.za/resources/docs/news/Energy_2011-09-22_Publication_New_standard.pdf). Municipalities are

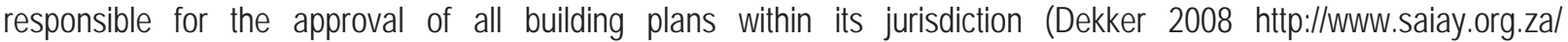
NRB\%20AND\%20DTS\% 20STANDARDS.pdf.) and therefore it can be expected of municipalities to use their legislative and executive powers in such a way that it will result in compliance with SANS 10400-X.

\section{Voluntary Standards}

SANS $26000 /$ ISO 26000 provides guidance to organisations in relation to issues such as human rights, environmental management, climate change and community development. This is a voluntary guidance standard, and is not intended for certification purposes, however this standard can be used in how organisations and in this specific study how local governments can integrate social responsibility within their core activities and throughout their sphere of influence (National Committee SABS 2010 www.sabs.co.za).

\section{Challenges/Opportunities}

The barriers to energy efficiency in the South African building industry and possible solutions to the resistance to the implementation of energy conservation possibilities is addressed. The challenges that are foreseen is in order to achieve sustainable development, there is a need to move towards renewable and sustainable energy production that is coupled with improved energy efficiency. The implementation of policies and laws that mandate renewable energy has also been hampered by the misalignment between the South Africa's energy laws generally and environmental laws that aims to promote sustainable development. No synchronisation between the environmental laws, energy laws and the local government laws of South Africa exist. The contradictions between these "fields" of laws and policies have negative impacts on the effectiveness of the law in fostering pathways towards sustainable renewable energy. Local government for instance with the principle of subsidiarity is best situated to promote small-scale renewable energy projects, and also to promote the rollout of the national projects such as solar water-heating. Local governments are also best suited to promote or implement voluntary projects or standards such as SANS 50001:2011 (Murombo and Du Plessis Energy Efficiency: New Strategies for improving South African Energy Laws). 


\section{Conclusion}

- There is a call for the transition to renewable energy and this must be concurrent with the instilling of energy use disciplines in the mind of energy users.

- South Africa accustomed to an environment of cheap electricity and therefore there had been no motivation to be efficient with energy usage.

- There must be a mind-set change to promote energy efficiency and sustainable housing.

- There are various tools in order to achieve this: laws, policies, strategies, guidelines and voluntary projects.

- Promote and develop energy efficiency practices, norms and standards in different energy sectors, including industries, commercial buildings, households, transport and agriculture.

- Promote energy for sustainable development.

- Facilitate information awareness and capacity building campaigns on energy efficiency and environmental issues.

- Mitigate negative impact of energy utilization on environment.

- Promote energy efficiency technologies, clean energy technologies including environmentally sound energy technologies.

\section{References}

Bamford M Brownfield vs Greenfield Sites: What are the issues involved? [Online] Available: http://www.geography.org.uk/ download/GA_PRICTIdea16IssuesActivity.pdf

Bekink, B., (2008), Principles of South African Local Government Law. Durban: Lexis Nexis.

Brand, D. and Heyns, C., (2005), Socio Economic rights in South Africa. Pretoria: PULP.

Constitution of the Republic of South Africa, (1996)

Davenport, (2008) South Africa's first green building rating tool. [Online] Available: http://www.engineeringnews.co.za/print-version/sasfirst-green-building-rating-tool.

GG R711 no 34586 of 9 September 2011

Green Building Council of South Africa, (2011), Green Building Council SA. [Online] Available: http://www.gbcsa.org.za

Income Tax Act 58 of 1962

Lemmer, (2011), The KwaZulu-Natal Institute for Architecture. [Online] Available: http://www.kznia.org.za/resources/docs/news/ Energy_2011-09-22_Publication_New_standard.pdf.

Local Government: Municipal Systems Āct 32 of 2000

Murombo, T. and Du Plessis, W., (2012) Energy Efficiency: New Strategies for Improving South African Energy Laws. [Online] Available: http://www.elasa.co.za/uploads/1/1/8/2/11823994/presentation_proff_willemien_du_plessis_and_tumai_murombo.pdf

Naional Committee SABS, (2011), SANS 10400-XA:2011 (South African National Standard). [Online] Available: www.sabs.co.za

National Building Regulations and Building Standards Act 103 of 1977

National Energy Act 34 of 2008

National Environmental Management Act 107 of 1998

Ottawa, (2010) Brownfield redevelopment Community Improvement Plan. [Online] Available: http://ottawa.ca/sites/ottawa.ca/files/ migrated/files/con025271.pdf

Siemens, (2010) Transforming cities for the better through sustainable technology. [Online] Available: http://www.us.siemens.com/ sustainable -cities/index.html.

White Paper on Local Government, 1998 